\title{
Physical and Chemical Characterization of a Protected Wetland Area in EI Fondo d'Elx (Alicante, Spain)
}

\author{
Maria A. Rodrigo' ${ }^{1}$ Xavier Armengol ${ }^{1}$, Rafael Oltra ${ }^{1}$ and William Colom ${ }^{2}$ \\ 'Institut Cavanilles de Biodiversitat i Biologia Evolutiva. Universitat de Valencia. E46100-Burjassot (Valencia) \\ Spain. Tel.: Int+ (34-6) 35435 86; Fax number: Int+ (34-6) 35436 70; E-mail: Maria.A.Rodrigo@uv.es \\ ${ }^{2}$ Fundació Mediambiental. Músico Gomis, nº 2. E46100-Burjassot (Valencia) Spain. Tel.: Int+ (34-6) 36394 94; \\ Fax number: Int+ (34-6) 3644720
}

\begin{abstract}
Two shallow ponds (Southeast and Southwest ponds) of El Fondo d'Elx wetland and their contributing inflows are described in their physico-chemical features during one year (November 1994 to October 1995). Conductivity increased as water level decreased due to high evaporation and minimal water inputs under drought conditions caused both by the weather and overexploitation of groundwater resources in the area. Initially considered mesohaline, the waters were re-classitied as polyhaline from July 1995. Extensive agricultural activities and the intensive use of nitrogenous fertilizers occur in surrounding lands have resulted in high nitrate concentrations, and frequently high N/P ratios, in inflow waters. Other human activities, such as reed burning and the opening of paths have disturbed the sediment, also leading to phosphorus enrichment, which has also been followed by large algal blooms at some sites. The Southeast Pond was subject to successive dessication-flooding cycles. After the flooding of the dry sediment, high concentrations of nitrogen compounds and soluble reactive phosphorus were detected, which were quickly depleted, possibly dueto uptake by phytoplankton. The Southwest Pond, which did not dry out had lower nutrient concentrations, lower salinity, higher water transparency and the continuous presence of aquatic macrophytes throughout the year.
\end{abstract}

key words: Mediterranean wetland, desiccation-flooding cycles, salinity, nutrients

\section{RESUMEN}

Se ha estudiado el ciclo anual (noviembre 1994-octubre 1995) de algunas variables fisico-quimicas en las charcas Sureste y Sur de Poniente del Fondo d'Elx. La conductividad del agua aumentó a lo largo del período de estudio a medida que el nivel de las aguas descendía, debido a la elevada evaporación y a las mínimas entradas de agua causadas por la sequía, originada ésta por las condiciones meteorológicas y la sobreexplotación de los recursos hidricos en la zona. Al comienzo del período de estudio, en otoño, las aguas eran mesohalinas, aunque adquirieron la condición de polihalinas en el verano siguiente. Las actividades agrícolas, con el uso de grandes cantidades de fertilizantes en las áreas de alrededor; originan elevadas concentraciones de nitrógeno en las aguas que llegan hasta las charcas y, frecuentemente, la relación N/P es muy elevada. Otras actividades humanas (la quema controlada del carrizo y la apertura de canales que lleva asociada la resuspensión del sedimento).produjeron un aporte de fósforo que estuvo acompañado de densos florecimientos algales en algunos puntos. La charca Sureste estaba sujeta a sucesivos ciclos de desecado e inundación. En los momentos posteriores a la inundación sobre los sedimentos secos, se detectaron elevadas concentraciones de compuestos de nitrógeno y fósforo, las cuales descendieron considerablemente en menos de un mes, posiblemente asimilados por elfitoplancton. La charca Sur de Poniente no se secó y se diferenció de la anterior al presentar las concentraciones más bajas de nutrientes, menor salinidad, mayor transparencia del agua y la presencia continua de macrófitos sumergidos a lo largo del año.

Palabras clave: humedal mediterráneo, ciclos desecado-inundación, salinidad, nutrientes

Limnetica $2 \mathrm{I}(\mathrm{I}-2): 37-46(2002)$

(C) Asociación Española de Limnología, Madrid Spain. ISSN: 0? 13-8409 


\section{INTRODUCTION}

Humid coastal areas are in regression due to human interference (Kent, 1994). A major problem of the Mediterranean coastal wetlands is an excessive input of nutrients ( $\mathrm{N} \& \mathrm{P}$; Mesnage \& Picot, 1995). The sediment of these wetlands can alternately serve as a reservoir by fixing phosphate and other nutrients, oras a source when this phosphate is released under certain conditions. Also, in Mediterranean regions many shallow water bodies such as marshes, shallow lakes, rivers and man-made lakes desiccate partly or completely from the end of spring or beginning of suminer. Desiccation has a strong impact on the sediment chemistry (De Groot \& Golterman, 1994). El Fondo d'Elx is a Mediterranean wetland stressed by both environmental factors and human activities. Situated within a protected natural area, it is an important ecosystem especially for nesting and migrating bird populations and has been designated as a Ramsar site and as a Special Protection Area (European Community Directive 79/409, Wild Birds Directive). It is home to endemic and endangered species, such as the plant Limonium santapolense, and the cyprinodontid fish Aphanius iberus.

El Fondo d'Elx was originally a natural lagoon, but was modified in 1932 by an irrigation project being divided into two large reservoirs. Vestiges of the old lagoon surround the reservoirs. For instance, the Southwest and Southeast ponds. Data on physical and chemical characteristics of El Fondo d'Elx waters are scarce (López, 1983; López \& Tomás, 1989; Colom \& Rodrigo, 1993). Recently, the Southeast Pond

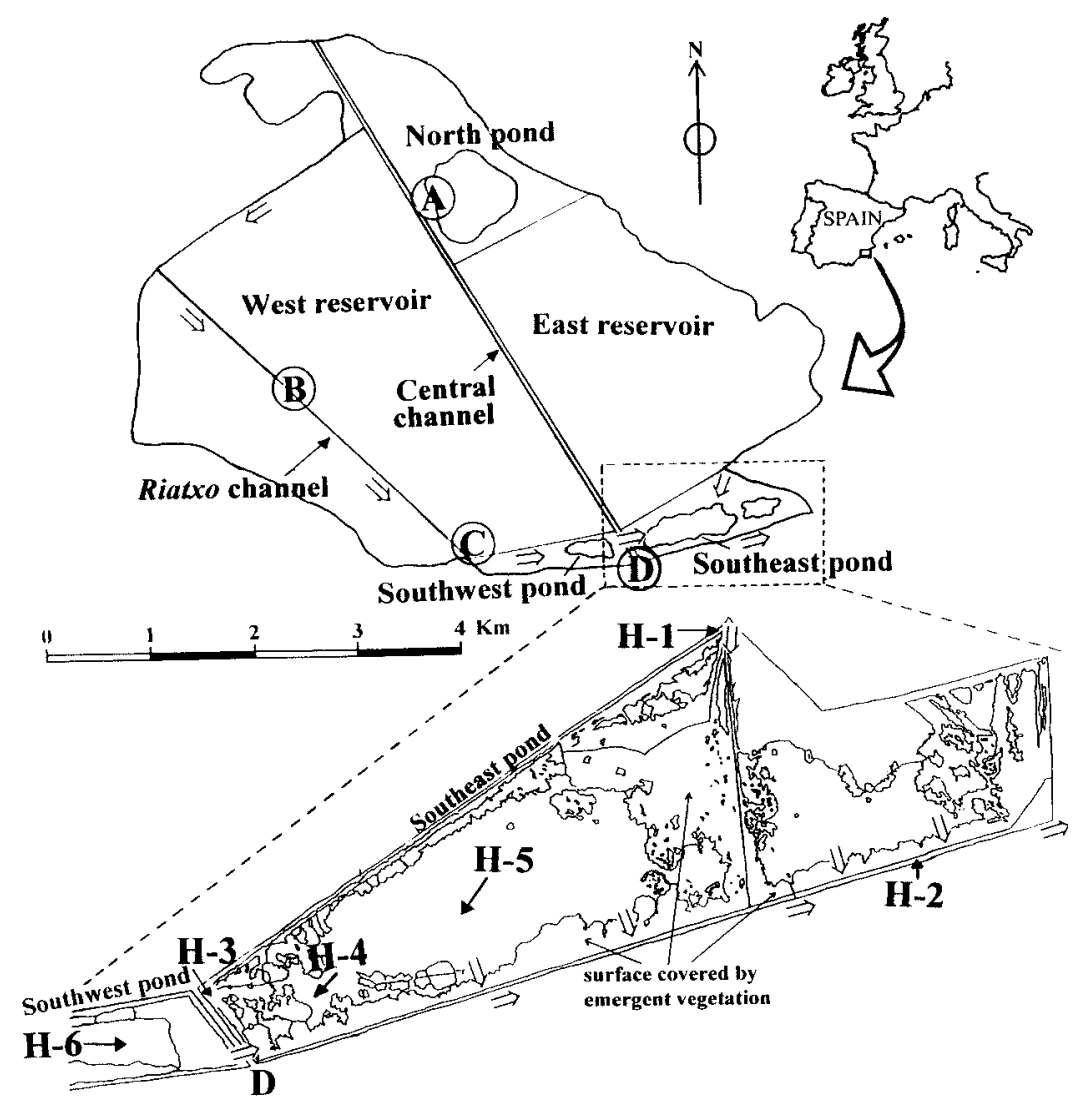

Figure 1. Location of the siudy area El Fondo d'Elx; sampling stations (H-1 to tí-6 and A to D) are sliown. The scale is for the top niap. The arrows indicate the direction of water flow. Situación del area de estudio El Fondo d'Elx. se indicun las estaciones de muestreo (de H-1 a H6 y de A и D). La escala corresponde al muptr superior Las flechas indicun la dirección de circulación del agua. 
was purchased by the Valencian Environmental Agency for its management and more detailed information on its water chemistry is now needed. The physical and chemical characteristics of Southwest and Southeast ponds were followed during one year (November 1994 to October 1995). Contributing water inflows were also monitored. The results presented here belong to a larger study which covers other limnological aspects, i.e. plankton, hydrology and botany. This study provides a limnological baseline against which future situations, deemed both good and bad, can be compared.

\section{STUDY AREA}

El Fondo d'Elx wetland in Alicante (Spain) covers an area of approx. 1500 ha (Fig. 1). It is 8 $\mathrm{km}$ from the Mediterranean coast. The climate is arid (Font, 1983). Initially a natural lagoon, it has been modified by an irrigation project. In order to elevate the water level, a dike surrounding the lagoon was constructed using sediment extracted from the lagoon and stabilized with vegetation. A channel was also built in the middle of the lagoon (Fig. 1) which divides it into two large reservoirs: East (4.50 ha) and West (650 ha), with capacities of 5 and 11 millions of $\mathrm{m}^{3}$, respectively. When full, their maximum depth is $2.5 \mathrm{~m}$. The hydrology of the lagoon is now artificially controlled. Water flowing into the lagoon is pumped from the Segura River, located about $15 \mathrm{Km}$ from the lagoon. Water also enters as runoff from extensively irrigated cultivation areas. Seawater enters the wetland mainly by seepage, but also through channels (López, 1983). The Southwest and Southeast ponds (WP and EP hereafter) are remnants of this old lagoon. Both water bodies are shallow, with a maximum depth of $0.95 \mathrm{~m}$ in WP, $2 \mathrm{~m}$ in the west edge of EP and $0.6 \mathrm{~m}$ in its centre. The reservoir and its ponds are surrounded by emergent vegetation. In some ponds there are densely-rooted macrophyte beds of Chara hispida var haltica, Ruppia maritima var. maritima, Najas marina and Potamogeton pectinatus. EP has almost no macrophytes (Cirujano et al., 1995). The system of wetlands is used by many migratory birds (e.g. Botaurus stellaris, Platalea leucorodia, Phoenicopterus ruber, ...) and provides nesting habitat for dense populations of birds (e.g. Egretta garzetta, Bubulcus ibis, Nycticorax nycticorax, Ardeola ralloides, A. purpurea, Oxyura leucocephala, Marmaronetta angustirostris, Aythya ferina, ...; Grimmett \& Jones, 1989).

\section{MATERIAL AND METHODS}

Monthly water samples were taken from November 1994 to October 1995 at six stations (H-1 to H-6; Fig.1). H-1 was located at the start of a channel flowing to EP. H-2 was situated in the channel receiving waters from EP. Three stations were located in EP, i.e. H-3, a deeper area near the west shore, $\mathrm{H}-4$ in an open area surrounded by emergent vegetation, and $\mathrm{H}-5$ in the middle of the main water body. A single sampling station (H-6) was situated in the centre of WP. Additionally, water samples were taken seasonally (December 1994, April, July and October 1995) from the input channel to WP (Riatxo channel, stations A, $\mathrm{B}$ and $\mathrm{C})$, and at Station D, in the channel between WP and EP (Fig.1). All water samples were taken at $0.15 \mathrm{~m}$ from the surface.

Standard limnological and chemical determinations were made at each station. In situ readings for temperature, dissolved oxygen and its saturation percentage, redox potential, conductivity, $\mathrm{pH}$ and sodium, were obtained. Water samples were also collected at each station for chemical and pigment analyses. Samples were processed within 24 hours from collection. Pigment determinations were made by filtering appropriate water volumes, depending on cell density, through Whatman GF/F glass fibre filters $(0.7 \mu \mathrm{m}$ pore size). The pigment extraction was made with $90 \%$ acetone, measured by spectrophotometry and then calculated according to Jeffrey and Humphrey (1975). Alkalinity, calcium and magnesium were measured volumetrically after titration (Rodier, 1989). Sulfate was determined by turbidimetry (A.P.H.A. 1980). 
Table 1. Annual average and standard deviation (in brackets) of limnological variables in the East Pond (EP; sampling stations H-3, H-4, H-5) and in the West Pond (WP; sainpling station H-6) and their inflows (see text). Stations have been arranged following the main water flow direction. Undetec.: undetectable. Medias anuales y desviación estándar (entre paréntesis) de algunas variables limnológicas en EP (H-3, H-4, H-5) y WP (H-6) y sus entradas (ver testo). Lus estaciones están ordenadas siguiendo la trayectoria principal del agua. Undetec. : indetectable.

\begin{tabular}{|c|c|c|c|c|c|c|c|c|c|c|}
\hline & $\begin{array}{l}\text { Chl. } a \\
\mu \mathrm{g} \mathbf{l}^{-1}\end{array}$ & $\begin{array}{l}\text { SRP } \\
\text { pg }\left.\right|^{-1}\end{array}$ & $\begin{array}{c}\text { DIN } \\
\text { mg l}^{-1}\end{array}$ & $\begin{array}{l}\text { Eh } \\
\text { mV }\end{array}$ & $\begin{array}{l}\text { Alk. } \\
\text { meq } \mathrm{l}^{-1}\end{array}$ & $\begin{array}{c}\text { Sulphate } \\
\text { meq } \mathrm{I}^{-1}\end{array}$ & $\begin{array}{c}\text { Chloride } \\
\text { meq } \mathbf{I}^{-1}\end{array}$ & $\begin{array}{c}\text { Sodium } \\
\text { meq } \mathbf{I}^{-1}\end{array}$ & $\begin{array}{c}\text { Calcium } \\
\text { meq } \mathbf{l}^{-1}\end{array}$ & $\begin{array}{l}\text { Magnes. } \\
\text { meq } \mathbf{~ I}^{-1}\end{array}$ \\
\hline $\mathbf{A}$ & $6(3)$ & $2.5(2.9)$ & $5(3)$ & $203(56)$ & $6.2(1.0)$ & $63(7)$ & $113(6)$ & $106(13)$ & $24(1)$ & $30(8)$ \\
\hline B & $9(6)$ & $1.8(2.4)$ & $4(2)$ & 209 (74) & $6.2(0.5)$ & $63(7)$ & $115(8)$ & $110(12)$ & $27(3)$ & $37(2)$ \\
\hline C & $23(20)$ & $1.3(2.5)$ & $2(2)$ & $204(54)$ & $6.4(0.6)$ & $71(18)$ & $128(19)$ & $113(15)$ & $28(2)$ & $38(3)$ \\
\hline H-6 & $18(11)$ & $0.5(1.5)$ & $1(1)$ & $204(63)$ & $5.0(1.6)$ & $109(58)$ & $187(89)$ & $217(161)$ & $38(12)$ & $62(30)$ \\
\hline D & $34(16)$ & Undetec. & $3(5)$ & $272(150)$ & $5.4(0.7)$ & $111(54)$ & $253(116)$ & $199(134)$ & $37(9)$ & $69(35)$ \\
\hline H-3 & $33(28)$ & $1.5(3.4)$ & $5(7)$ & $216(72)$ & $5.3(0.8)$ & $128(66)$ & 232 (129) & $228(167)$ & 38 (12) & $78(45)$ \\
\hline $\mathrm{H}-4$ & $36(33)$ & $3(4.8)$ & $1(1)$ & $201(93)$ & $4.5(0.5)$ & $147(92)$ & $268(176)$ & $234(234)$ & $44(15)$ & $92(67)$ \\
\hline H-5 & $37(30)$ & Undetec. & $1(1)$ & 237 (111) & $4.2(0.6)$ & $123(34)$ & $224(68)$ & $172(120)$ & $39(7)$ & $74(30)$ \\
\hline H-1 & $39(57)$ & $9.2(10.8)$ & $10(7)$ & $213(41)$ & $7.1(1.5)$ & $87(55)$ & $172(114)$ & $156(121)$ & $31(7)$ & $54(45)$ \\
\hline H-2 & $242(405)$ & $6.3(17.5)$ & $1(1)$ & $192(62)$ & $4.2(0.8)$ & $159(55)$ & 299 (131) & $306(240)$ & $42(7)$ & $95(38)$ \\
\hline
\end{tabular}

Chloride, nitrate, nitrite, ammonium and soluble reactive phosphorus determinations were performed by colorimetry (A.P.H.A., 1980; Murphy $\&$ Riley, 1965). Salinity was calculated from the sum of the major ions. Water transparency was measured by means of a Secchi disk.

\section{RESULTS}

The ions followed the sequence $\mathrm{Cl}^{-}>\mathrm{SO}_{4}{ }^{=}>$ $\mathrm{HCO}_{3}^{-}$and $\mathrm{Na}^{\prime}>\mathrm{Mg}^{\prime}>\mathrm{Ca}^{2+}$ (Table 1). At the start of the study, waters from all sampled ponds and channels were mesohaline. Figure 2 shows the limnological characteristics of Riatxo channel (sampling stations A, B and C). Water temperature changes followed the annual temperature regime, with high values during the warm season. Water circulating through this channel was less saline than that found in ponds (Table 1; Fig. 2). However, conductivity increased during the annual cycle from $8-9 \mathrm{mS} \mathrm{cm} \mathrm{cm}^{-1}$ recorded in November 1994 to $12-13 \mathrm{mS} \mathrm{cm}^{-1}$ in the Summer 1995. Average alkalinity in the channel was higher than in the ponds (Table 1). The annual average ofdissolved oxygen ranged between 6 and 8 mg $\mathrm{O}_{2} 1^{-1}$ (Fig. 2B) with saturations of 67 to $89 \%$. The average $\mathrm{pH}$ values in the channel were slightly lower than those recorded in the ponds.
Nutrient cycling in Riatxo channel was substantial. For example, in December 1994, nitrate concentration was higher at Station A $(9 \mathrm{mg}]^{-} \mathrm{N}$ $\mathrm{NO}_{3}^{-}$) than at either B (6.8 mg I-' N-NO;) or C (3.4 $\mathrm{mg} \mathrm{I}^{-1} \mathrm{~N}^{-\mathrm{NO}_{3}}{ }^{-}$). The decreasing trend in nitrate concentration along the channel was observed during the following months, also for nitrite and soluble reactive phosphorus (SRP; see Figs. 2F, 2G \& 2H). In contrast, chlorophyll $a$ concentrations increased along the channel (Fig. 2). The pigment content reached its peak at all sampling stations during the warm season.

Water from the Riatxo channel inflows the Southwest Pond (WP; station H-6). At the end of November 1994, water depth was $0.9 \mathrm{~m}$ at H-6 and decreased to $0.2 \mathrm{~m}$ during the warm season. Aquatic vegetation covered a large part of the bottom. In contrast to the other sampling stations, water transparency in WP was high throughout the entire study period, with the bottom being visible at all times. Water temperature was near $30^{\circ} \mathrm{C}$ during the warm season (Fig. 3A). Dissolved oxygen and $\mathrm{pH}$ showed large fluctuations throughout the year (Fig. 3B-D). Conductivity at the beginning of the study was $9.5 \mathrm{mS} \mathrm{cm}^{-1}$ with a September maximum of 31 $\mathrm{mS} \mathrm{cm} \mathrm{cm}^{-1}$ (Fig. 3C). A decrease in water conductivity and increase in water level were recorded in October following rains (Fig. 31). The ammoni- 
Physical and chemical characterization of a protected wetland area (El Fondo d'Elx, Spain). 41
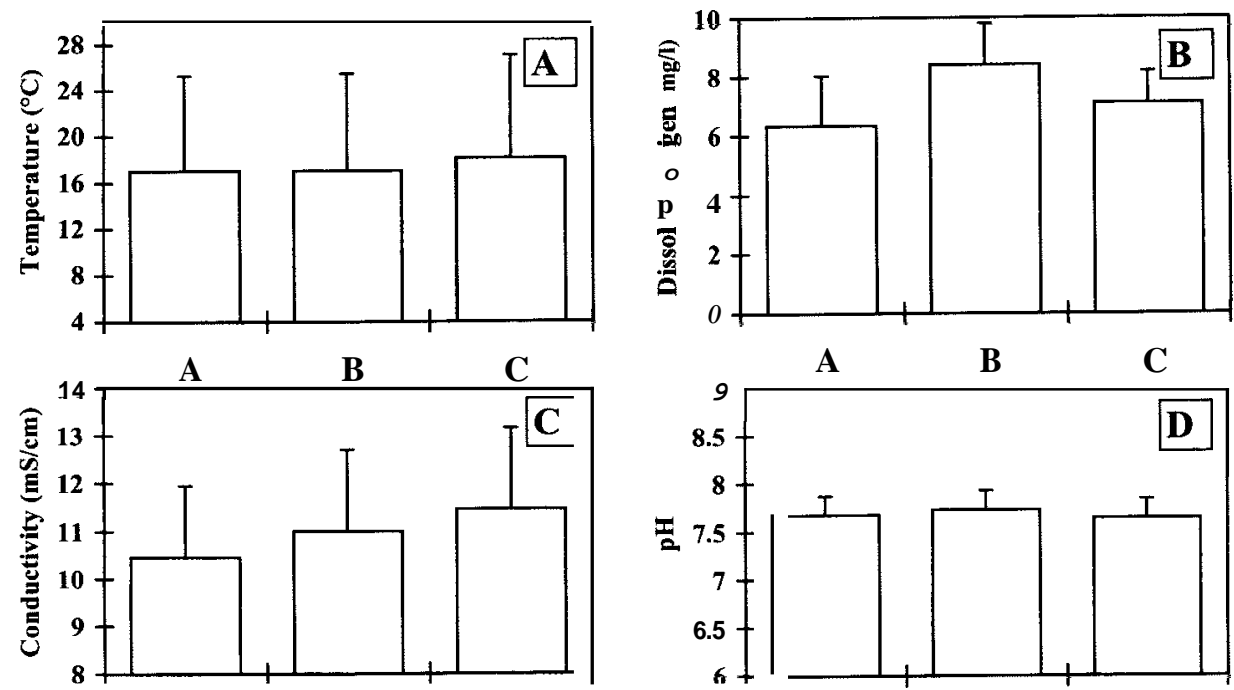

A

B

C

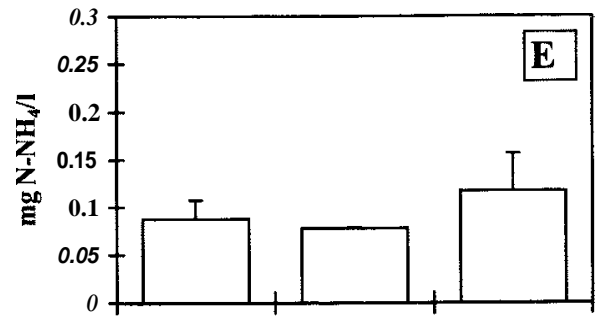

A

B

C

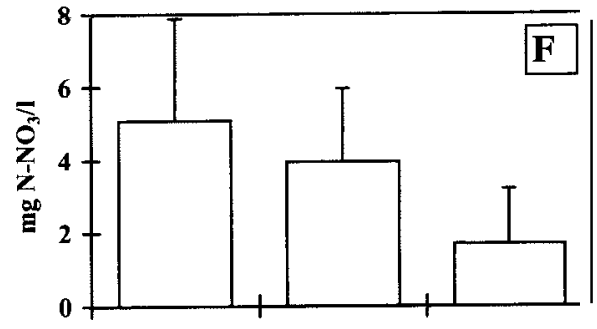

$\mathbf{A}$

B

C

A

B

C
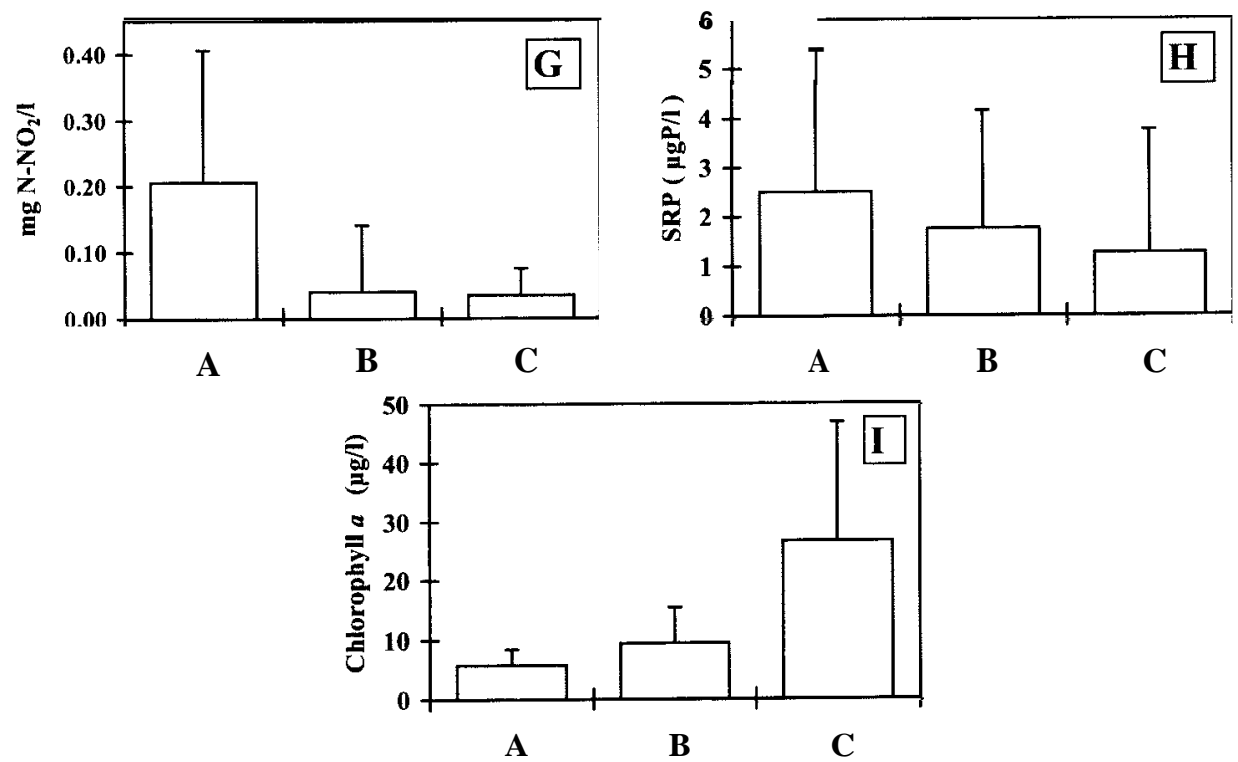

Figure 2. Annual average values for limnological paratneters in the Riatxo channel (stations A, B and C). Vertical bars indicate standard deviations. Valores medios anuales para un conjunto de variables del canal del Riatxo (estaciones $A, B$ y $C$ ). Lu barras verticales indicun las desviuciones estándar. 

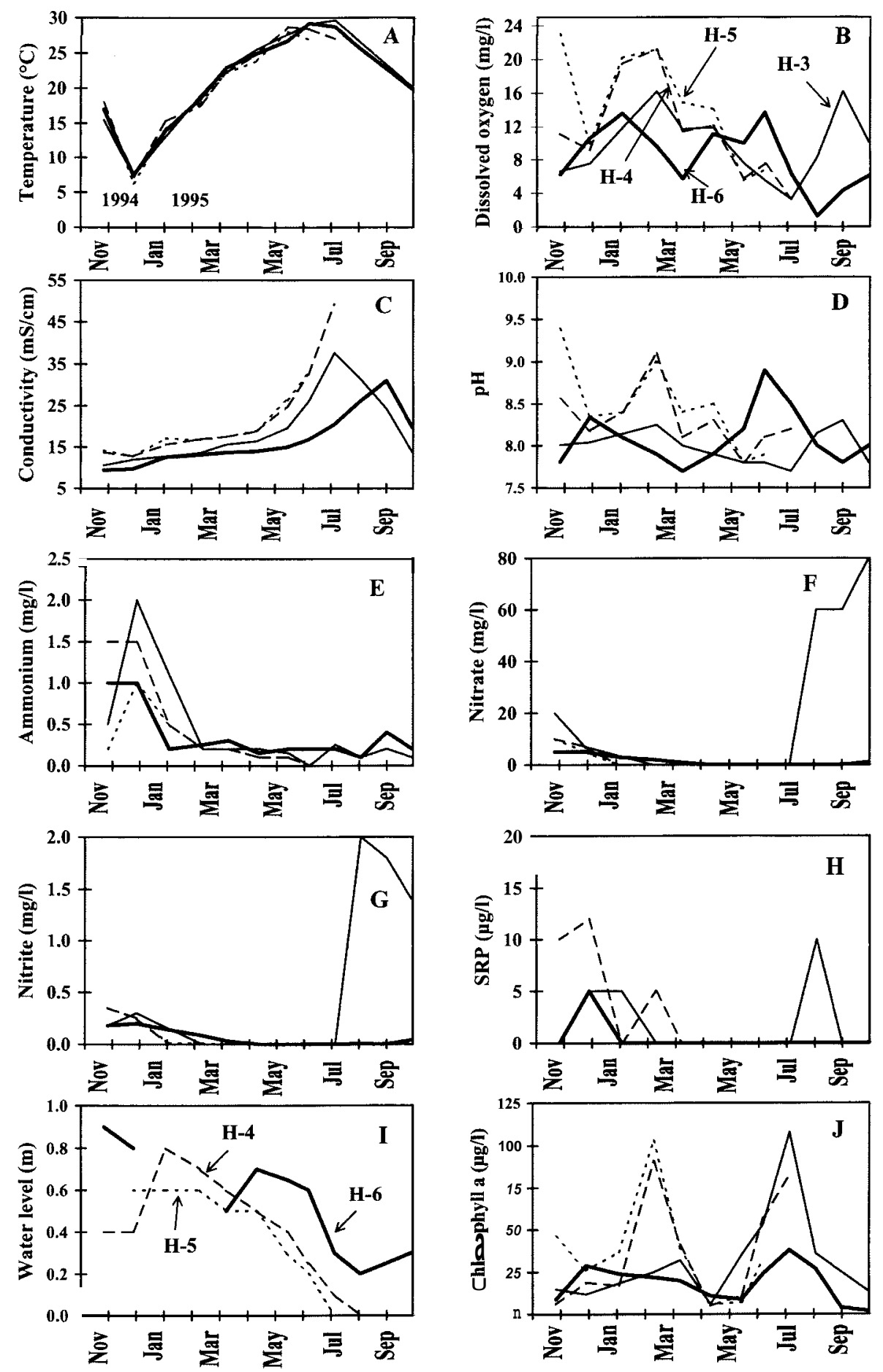

Figure 3. Annual variations of limnological parameters in the Southeast Pond (H-3, H-4 and H-5) and in the Southwest Pond (H-6) Variacionesanuales en los parámetros limnológicos de la charca del Sudeste $(H-3, H-4$ y H-5) y de la charca del Sudoeste (H-6). 
um concentration reached a maximum at the end of $1994\left(0.8 \mathrm{mg} \mathrm{l}^{-1} \mathrm{~N}-\mathrm{NH}_{4}^{+}\right)$and then decreased to below $0.4 \mathrm{mg} \mathrm{l}^{-1} \mathrm{~N}-\mathrm{NH}_{4}^{+}$. Nitrate concentrations were generally low, with an annual average of $0.32 \mathrm{mg} \mathrm{l}^{-1} \mathrm{~N}-\mathrm{NO}_{3}^{-}$(Fig. 3F). WP had the lowest nitrite concentrations (Fig. 3G). SRP concentrations were nearly undetectable during most of the year, although a max. of $5 \mu \mathrm{g}-\mathrm{P}^{-1}$ was reached in December 1994. The chlorophyll $a$ concentration ranged between 2 and $38 \mu \mathrm{g} \mathrm{I}^{-1}$. The minimum was achieved in October, after the seasonal rains (Fig. 35).

Station D was located in the channel flowing from WP to EP (Fig. 1). The conductivity at Station D was close to that measured at H-6 (WP). However, the former greatly increased during July, while the latter only did slightly. Changes in alkalinity at Station D were similar to those at H-3 (EP). Nitrate and nitrite concentrations were low. However, from July 1995 an increase in nitrogen species similar to that found at H-3 was observed at Station D (Fig. 3F,G). SRP remained undectable. The highest chlorophyll $a$ concentration was recorded in April 1995 $\left(53 \mu \mathrm{g} \mathrm{l}^{-1}\right)$ and it progressively declined to $18 \mu \mathrm{g}$ $1^{-1}$ by the end of the sampling period.

Runoff from surrounding agricultural lands was directly discharged into a channel $\mathrm{H}-1$, then flowing into EP. Discharges were observed during the sampling period, with the exception of February, April, June and the beginning of August. The highest oxygen concentrations were recorded at times of no discharge (i.e. $22 \mathrm{mg} \mathrm{l}^{-1}$ in February). When there was inflow into the channel, oxygen content was lower, although always in excess of $8 \mathrm{mg} \mathrm{l}^{-1}$. This difference was due to the dilution of channel water with lower-conductivity water pumped into the channel. Conductivity at $\mathrm{H}-1$ thus varied depending upon the amount of less conductive water discharged to the channel from the pipe. The lowest conductivity for the entire zone was recorded at H-1 (7.1 $\mathrm{mS} \mathrm{cm}{ }^{-1}$ ) in November 1994. The $\mathrm{pH}$ was higher than 7.5 on all occasions. Total alkalinity was high (Table 1), and mainly due to $\mathrm{HCO}_{3}^{-}$, particularly when surplus water was being discharged into the channel. A maximum Chlorophyll $a$ con- centration of $184 \mu \mathrm{g} \mathrm{l}^{-1}$ was reached in April 1995. The mean concentration of nitrate was 10 $\mathrm{mg} \mathrm{l}^{-1} \mathrm{~N}-\mathrm{NO}$; with a maximum of $23 \mathrm{mg} \mathrm{l}^{-1} \mathrm{~N}$ $\mathrm{NO}_{3}^{-}$. Large concentrations of nitrite occurred in February and May (i.e. 0.04-0.15 $\mathrm{mg}^{-1} \mathrm{~N}^{-\mathrm{NO}_{2}}{ }^{-}$). SRP averaged $9.2 \mu \mathrm{g} \mathrm{l}^{-1}$, reaching on occasions 20-30 $\mathrm{g} \mathrm{I}^{-1}$, when water was being discharged into the channel from surrounding lands.

For several years, the Southeast Pond (EP, stations $\mathrm{H}-3, \mathrm{H}-4$ and $\mathrm{H}-5$ ) has experienced successive desiccation-flooding cycles, both natural and induced by overexploitation of groundwater. During the summer and early autumn of 1994, a large area of the pond remained completely dry. Sampling began at the end of November 1994, about one month after the pond had flooded again. At that time, water depth was $0.4 \mathrm{~m}$ at Station H-4 and $1.5 \mathrm{~m}$ at $\mathrm{H}-3$. Water conductivity ranged from 11 to $13 \mathrm{mS} \mathrm{cm}^{-1}$ (Fig. 3C). At the beginning of February, maximum depths of $0.6 \mathrm{~m}$ and $0.8 \mathrm{~m}$ were measured at $\mathrm{H}-5$ and $\mathrm{H}-4$, respectively (Fig. 31). As water levels dropped, conductivity increased (Fig. 31) by a factor of 2.3 to 3.6 (Fig. 3C) until mid-July at Station H-5 and by midAugust at Station H-4. At H-3, in contrast, conductivity increased until mid-August, and then decreased (Fig. 3C). No rains fell during that time to cause the lower conductivity. However, higher runoff entered the pond. Stations H-4 and H-5 had high dissolved oxygen concentrations (Fig. 3B) at the end of winter and the beginning of spring. From March, dissolved oxygen levels started to decrease, as well as pH values and chlorophyll $a$ concentrations (Fig. 3D \& 35). The maximum pH coincided with dissolved oxygen peaks at both stations $(r=0.77-0.99 ; n=8)$. Water transparency decreased due to an increase in the amount of detritic material, composed of dead plankton which had collapsed with the high salinity.

During the first months after flooding at Stations $\mathrm{H}-4$ and $\mathrm{H} 5$ in the EP, the concentrations of inorganic compounds of nitrogen were 0.9-1.2 $\mathrm{mg} \mathrm{l}^{-1} \mathrm{~N}^{-\mathrm{NH}_{4}}+, 2.3 \mathrm{mg} \mathrm{l}^{-1} \mathrm{~N}-\mathrm{NO}$; and $0.05-0.11$

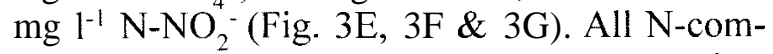
pounds declined to almost undetectable els during the rest of the sampling period. In August, significant increases in nitrate and nitrite contents 
were recorded at Station H-3 (Fig. 3F-G). Nitrite decreased from a maximum of $0.61 \mathrm{mg} \mathrm{l}^{-1} \mathrm{~N}-\mathrm{N}$ $\mathrm{NO}_{2}{ }^{-}$at the end of August to $0.42 \mathrm{mg}$ I- $^{-} \mathrm{N}-\mathrm{N}$ $\mathrm{NO}$; one month later (Fig. 3G). SRP reached a maximum of $10 \mu \mathrm{g} \mathrm{l}^{-1}$ so at the end of August. Chlorophyll a content peaked at near $100 \mu \mathrm{g} \mathrm{l}^{-1}$ in March at H-4 and H-5, and then declined until May (Fig. 35).

The channel receiving waters from EP (station $\mathrm{H}-2$ ) showed a maximum of water conductivity of $53 \mathrm{mS} \mathrm{cm}^{-1}$, a four-fold increase over the study period. Remarkably high chlorophyll a concentrations were measured (i.e. a maximum of 1272 $\mu \mathrm{g}^{-1}$ in November 1994). During the algal bloom, $\mathrm{pH}$ levels were high $(\mathrm{pH}=9.9)$, dissolved oxygen values exceeded $20 \mathrm{mg} \mathrm{l}^{-1}$ and saturation was around $200 \%$. A few days prior to the November 1994 sampling, the reed bed fringing this channel was eliminated by burning by the wetland managers. The resulting ash entered the waters, providing a surplus nutrient supply for phytoplankton development, especially in the form of SRP, which reached concentrations of 60 $\mu \mathrm{g} \mathrm{1^{-1 }}$. One month later the SRP content had decreased to $15 \mu \mathrm{g}^{-1}$ and concentrations near 0 were recorded through to the end of the study period. Ammonium concentration was high the following months after the reed burning and started to decrease from May 1995 through to the end of the study. Nitrite and nitrate concentrations peaked $\left(0.21 \mathrm{mg} \mathrm{I}^{-1} \mathrm{~N}-\mathrm{NO}_{2}^{-}, 3.4 \mathrm{mg} \mathrm{l}^{-1} \mathrm{~N}-\mathrm{NO}_{3}^{-}\right.$) in July-August 1995 and then both decreased to undetectable values.

\section{DISCUSSION}

The Southwest and Southeast ponds in El Fondo d'Elx have received two main impacts. The first is the reduction in the period of flooding and thus the decrease in the volume of water contained in the basins. High potential evapotranspiration (i.e. $1202 \mathrm{~mm}$; Pérez, 1994) due to high temperatures, and low precipitation (i.e. approx. $200 \mathrm{~mm}$ ) have been responsible for lowering the water levels. A consequence of this situation has been a 2.5 to 4 fold increase in the salinity of these mesohaline waters. During the warm season, when salinity increased due to both higher evapotranspiration and overexploitation of groundwater resources, the waters could be classified as polyhaline (10$\left.17 \mathrm{~g} \mathrm{Cl}^{-1}{ }^{-1}\right)$. On the other hand, the ponds are eutrophicated. Based on chlorophyll and nutrient contents, the ponds can be classified as "eutrophic" (Margalef, 1983). Also, the composition of the phytoplankton and zooplankton assemblages (Rodrigo et al., 2001) were typical of eutrophic water bodies. Nevertheless, the WP had a lower trophic status at the end of the study period. Waters at Station H-2 were hypereutrophic on occasions (Barica, 1980). During these periods, the alga Gyrodinium aureum was dominant and directly responsible for the high chlorophyll concentrations measured. The controlled reed burning was a contributing nutrient source, especially of phosphorus. Also, managers opened up paths along shores, resuspending sediments, and potentially adding further to eutrophication. Thus, it is recommended that alternative measures having less impact on the ecosystem, be used to control emergent vegetation.

The EP received nutrients from diffuse sources, primarily from agricultural runoff (DíazÁlvarez, 1989) and through the channel (Station $\mathrm{H}-1$ ), in the form of nitrate. Consequently, the $\mathrm{N} / \mathrm{P}$ ratio was high for most of the year and at most of the study stations, suggesting $\mathrm{P}$ was the limiting factor of algal growth. After flooding, large concentrations of nutrients were measured in the water. Nutrients could have been released from the sediment into the shallow water column. De Groot \& Golterman (1994) found that desiccation had a strong influence on sediment chemistry and that evaporation at the sediment-air interface caused an upward water flux, resulting in the transport of dissolved compounds. Transport could be from at least $40-\mathrm{cm}$ deep, bringing to the surface organic compounds, nitrogenous compounds, ortophosphate and organic phosphate compounds. Several studies have been carried out on ricefields, which are ecosystems subject to alternative dry-flood cycles (Forés \& Sabater, 1987; Forés \& Comín 1987; Comín \& Forés 1990). These studies have 
shown that an important release of nitrogen in the forms of nitrate and ammonium occurs following flooding. Nitrification results in the accumulation of nitrates in the dry sediments (Standford \& Epstein, 1974). Nitrate is subsequently the dominant nutrient in the water once the sediments have been reinundated. A similar observation was made in the EP pond. On the other hand, it is possible that waters used to flood the pond had high nutrient concentrations. Sediment analyses are required in the EP to determine the possible sediment-water nutrient flux. Eutrophication of the pond could result because of internal loading. Regardless of the origin of the surplus nutrients, these nutrients stimulated algal growth, resulting in decreased water transparency, which in turn prevented the development of aquatic macrophytes. High levels of ammonium and nitrite were detected on a number of occasions. Several authors (Mattes \& Kreebs, 1974; Santamaría et al., 1994) have pointed out the toxic effects of ammonium salts on several species of submerged vegetation (e.g. Potamogeton densus, Ruppia drepanensis). They proposed a minimum level of $5 \mathrm{mg} \mathrm{l}^{-1} \mathrm{NH}_{4}^{+}$for detectable toxicity effects on submerged plants. Although this level was never reached in the EP during the study, it is possible that lower concentrations could have the effect of slowing down macrophyte growth, thus leading to the dominance of phytoplankton. On the other hand, the periods of drying out could go some way in explaining the scarce development of submerged macrophytes in the EP. The increase in nitrite at Station H-3 during September 1995 was particularly alarming, given the toxicity of $\mathrm{NO}$; for aquatic organisms.

The WP is the area with largest diversity of aquatic flora in the Natural Park of El Fondo d'Elx (Cirujano et al. 1995). This pond had higher water quality than the EP and never completely dried up. Water permanence is essential to allow growth of submerged macrophytes. Similar observations have been made in a coastal wetland in Mallorca, Spain (Ramon et al. 1994). The lower phytoplankton biomass found in this pond compared to the EP may have been due to competition with phytobenthos (i.e. macrophytes and epiphytic algae) for nutrients. More plant growth lead to higher water transparency, in turn favouring the development of a larger cover of submerged vegetation.

Data on nitrogen compound concentrations and chlorophyll data along the Riatxo channel show the process of self-depuration. Nutrients in the water are assimilated into biomass (i.e. into phytoplankton). As a result, the WP did not receive large nutrient inputs in a dissolved form. The Riatxo channel is surrounded by extensive beds of emergent vegetation, predominantly of reeds (e.g. Phragmites australis, Arundo donux, ...). Reed beds are thought to remove large amounts of nutrients from the water (Ansola \& De Luís, 1994). Thus, submerged vegetation growing in the channel could have also contributed to the removal of nutrients from the water, leading to a decrease in nitrate concentrations by the end of the channel.

\section{ACKNOWLEDGEMENTS}

This investigation was financially supported by project LIFE for the preservation of wetlands (Conselleria de Medi Ambient, Generalitat Valenciana (Spain) exp. 193/94). The authors wish to thank Carles Dolç, Jose Luís Echevarrías and Jose Aragoneses for assistance during field sampling. We also thank Moira Greaven and Gonum Reddy for revising the English version of the manuscript.

\section{REFERENCES}

ANSOLA, G. \& E. DE LUÍS. 1994. Concentración de nutrientes en heliófitos acuáticos utilizados en la depuración de aguas residuales. Limnetica. 10: 33-36.

A.P.H.A. 1980. American Public Health Association, American Water Works Association and Water Pollution Control Federation.- Standard Methods for the examination of water and wastewater 15th Edition. Washington D.C. U.S.A. 1134 pp.

BARICA, J. 1980. Why hypertrophic Ecosystems?. In Hypertrophic Ecosysteins (Barica, J. \& L.R. Mur eds.). Developments in Hydrobiology, 2. Junk. The Hague, 348 pp. 
CIRUJANO, S., L. MEDINA, J. B. PERIS \& G. STÜBING. 1995. Estudio de la floray vegetacion de los parajes naturales de las salinas de Santa Pola, El Hondo de Elche y las lagunas de La MataTorrevieja. Report. 237 pp.

COLOM, W. \& M. A. RODRIGO. 1993. Seguimiento limnológico preliminar de los humedales de la Comunidad Valenciana susceptibles de alberga los ciprinodóntidos endémicos Valencia hispanica (samaruc) and Aphanius iberus (fartet). Report. 181 pp.

COMÍN, F. A. \& E. FORÉS. 1990. Comprobación experimental de la importancia relativa de las vías superficial y subterránea de inundación en la liberación de sales de sedimentos desecados.- Scientia gerundensis, 16: 69-77.

DE GROOT, C. J. \& H. L. GOLTERMAN. 1994. Nutrient processes in Mediterranean wetland systems. Part 2. The influence of desiccation. Verh. Jnternat. Verein. Limnol., 25: 1328.

DIAZ-ÁLVAREZ, M. C. 1989. Contaminación agraria difusa. MOPU Secretaría de Medio Ambiente. 98 pp.

FONT, I. 1983. Climatología en España y Portugal. Instituto Nacional de Meteorología. Madrid. 458 pp.

FORÉS, E. \& F. A. COMÍN. 1987. Cheinical characteristics of the water in the ricefields of the Ebro Delta (N.E. Spain). Arch. Hydrobiol., 111: 15-24.

FORÉS, E. \& F. SABATER. 1987. Movilización del nitrógeno en los arrozales: interaction sedimentoagua durante la inundación. Pvoceedings $I V$ Spanish Congress of Limnology, 127-134. Spanish Association of Limnology. Sevilla.

GRIMMETT, R. F. A. \& T. A. JONES. 1989. Jmpovtant Bird Areas in Europe.- ICBP Technical Publication № 9.

JEFFREY, S. W. \& G. F. HUMPHREY. 1975. New spectrophotometric equations for determining chlorophylls a, b c1 and $\mathrm{c} 2$ in higher plants, algae and natural phytoplankton. Biochem. Physiol. Pflanzen., 167: 191-194.

KENT, D. M. 1994. Applied Wetlands Science and Technology. Ed: Lewis. 436 pp.

LÓPEZ, M. P. 1983. Aguas salinas epicontinentales próximas a las costa mediterránea española.
Estudio del medio.- Ph. D. Thesis. University of Barcelona.

LÓPEZ, M. P. \& X. TOMÁS. 1989. Chemical composition of the small coastal lagoons of the Mediterranean Spanish littoral. Topics in Marine Biology, 53: 591-599.

MARGALEF, R. 1983. Limnología. Ed. Omega S.A. Barcelona. $1010 \mathrm{pp}$.

MATTES, H \& K. KREEBS. 1974. Die Nettophotosynthese von Wasserpflanzen, insbesondere Potamogeton densus, als Indikator für die Verunreinigung von Gewassern. Angew. Botanik, 48: 287-297.

MESNAGE, V. \& B. PICOT. 1995. The distribution of phosphate in sediments and its relation with eutrophication of a Mediterranean coastal lagoon. Hydvobiologia, 297: 29-41.

MURPHY, J. \& J. P. RILEY. 1962. A modified singlesolution method for the determination of phosphate in natural waters. Analyt. chim. Acta, 27: 31-36.

PÉREZ, A. J. 1994. Atlas climàtic de la Comunitat Valenciana.- Ed. Generalitat Valenciana. 205 pp.

RAMÓN, G. A. BARÓN, M. I. FERNÁNDEZ, M. F. MASSANET, M. TUR, M. VICENS \& A. VIDAL. 1994. Fonts de l'Almadrava (Pollença), an unusual spring site on the island of Mallorca.-Verh. internat. Ver: Limnol., 25: 1452-1454.

RODIER, J. 1989. Análisis de las aguas. Aguas naturales, aguas residuales y agua de mar:- Ed. Omega, Barcelona. 1059 pp.

RODRIGO, M. A., ARMENGOL-DIAZ, X., OLTRA, R., DASÍ, M. J. \&. COLOM. W. 2001. Environmental variables and planktonic communities in two ponds of El Hondo wetland (SE Spain). Jnternat. Rev. Hydrobiol., 86: 299-315.

SANTAMARÍA, L., C. DÍAS \& M. J. M. HOOTSMANS.1994. The influence of ammonia on the growth and photosynthesis of Ruppia drepanensis Tineo from Doñana National Park (SW Spain). Hydrobiologia, 2751276: 219-231.

STANDFORD, G. \& E. EPSTEIN. 1974. Nitrogen mineralization-water relations in soils. Soil Sci. Soc. An. Proceed., 38: 103-107. 